\title{
The Implications of Epidemic Risks for Scholarly Communication and Higher Education Processes. Preliminary Remarks
}

\author{
Piotr Tafiłowski \\ ORCID 0000-0003-2798-3249 \\ Department of Information Studies, \\ Faculty of Journalism, Information and Book Studies, \\ University of Warsaw, Poland
}

\begin{abstract}
Purpose/Thesis: The aim of this paper is to reflect and to start a discussion on changes in scholarly communication, both in the field of scientific research and university instruction, during an epidemiological crisis.

Approach/Methods: Presented reflections on changes in scholarly communication are of theoretical nature. The text emerged from online discussions with second-year students taking the course on Scholarly Communication as a part of their degree in Information Space Architecture (Faculty of Journalism, Information and Book Studies, University of Warsaw), in March 2020.

Results and conclusions: The epidemic threat of the coronavirus (COVID-19), which has disrupted our social life in recent weeks, affects the communication processes in science as well. The most obvious effect of the pandemic in the area under discussion will be the development of distance learning methods and technologies. This may also increase the scope of scientific papers available in the open access. Changes are inevitable, therefore we encourage a reflection on their direction so that we can prepare for the shift and actively participate in the designing of the future form of the scholarly communication. Originality/Value: This type of consideration is justified by the current state of affairs. We are now in the middle of a transformation that needs to be acknowledged \& discussed to give it the desired direction as far as possible.
\end{abstract}

Keywords

COVID-19. Distance learning. Scholarly communication.

Received: 16 April 2020. Reviewed: 26 June 2020. Revised: 8 July 2020. Accepted: 10 November 2020.

\section{Introduction}

The situation we faced immediately after the outbreak of the COVID-19 pandemic was something completely new in the experience of modern societies, including the world of science. We have to deal with it on different levels of our life, not only in private but also in the social sphere. The pandemic has fundamentally changed our lives, habits and schedules. We should pay attention to this problem to consider how it affects the communication processes in science and, in university instruction which is its part.

The deliberations presented in this paper are primarily theoretical. We would like for this paper to be not only a collection of guidelines for coping with this difficult period, 
but also a starting point for further discussion. The pandemic is a serious test for the system of scholarly communication. It is worth pondering what this situation means for science in general, but also for our discipline (we assume that scholarly communication is a part of the communication studies [or: communication sciences]) and what effects it will have in the long term. We want to consider both the negative and positive sides of the situation. For, as in any crisis, it is not only threats that are apparent, but also new directions of development.

\section{Scholarly communication}

The issue of contemporary scholarly communication, within its framework of sharing information and knowledge, has already been studied and discussed many times in information studies literature (for more recent Polish scholarship see e.g. Cisek \& Sapa, 2007; Kotuła, 2013; Krakowska, 2008; Nahotko, 2010; Sapa, 2009; Świgoń, 2015; as well as references attached to those texts). Today, scholarly communication is increasingly reliant on new technologies, moving to the virtual world and taking on the characteristics of informal behavior (see Barjak, 2006; Genoni et al. 2005; Genoni et al. 2014; Nahotko, 2008, 171-175), which is particularly important in the current state of the art and helps to maintain these processes.

We can observe a multi-directional sharing of information and knowledge in social networks. Each user may be not only the recipient, but also the sender and very often an intermediary (broker) of information flowing through different channels, as well as transferred from one information channel to another. Knowledge sharing by researchers participating in online social networks takes many different forms: blogging, discussion on forums, editing Wikipedia (or more generally: activities on Wiki-type sites), posting on Twitter or Facebook, preprinting articles on social networking sites and so on.

This paper follows Emanuel Kulczycki in framing scholarly communication as a practice implemented on two levels:

- individual - publication of scientific papers, communication with other researchers, popularization of science, etc;

- social - maintaining the functioning of science as a kind of social practice.

Scholarly communication is a part of the scientific process and one of its stages, following the collecting, analysis and processing of data (source information). Therefore, communication in science is not only treated as "information about the work of scientists", but becomes a process that strengthens science itself (Kulczycki, 2012). Therefore, we are discussing about communication about science (liaison of scholars with the outside word) and within science as well. It also includes university instruction, as we understand it for the purposes of this study ${ }^{1}$.

\footnotetext{
1 We are aware, however, that university instruction is usually not featured in the scholarly communication cycles. See e.g. Borgman, 2007; Regazzi, 2015.
} 


\section{Transformative time}

The closure of many state institutions, including academic institutions and onsite classes conducted there, forces participants of scholarly communication processes to act in a situation previously unknown to them. The degree of disorganization of scientific activity is not as great as in other sectors (such as health care), but here too we are dealing with some measure of disorder. This situation forces us to make rapid adjustments, thanks to which the academy can continue to function to some extent. These are not only institutional changes, which take time to prepare, but also the change of habits and behaviors, breaking the functional schemes and routines developed so far. For if we dare to break the routine, we may experience it not only as a threat and a loss, but also an opportunity to open and develop new, yet untested routes in our life, work and research (Kozłowski, 2020).

All kinds of scholarly meetings (regular stationary classes, conferences, symposia, conventions, but also daily interactions with fellow researchers) are replaced by remote contact, facilitated by digital technologies, or suspended at all. According to the regulation of the Polish Ministry of Science and Higher Education, all collegiate bodies, such as promotion committees, scholarship committees, electoral colleges, etc., as defined in the university's statutes, are to operate remotely. As a result, some delays are going to occur, e.g. in important for our milieu matters of granting of scientific degrees and promotions. Moreover, the period subjected to applying quantitative measures has been extended for one more year for universities. These are forced changes, which for the time being we have to accept.

Nevertheless, we are in such a lucky situation that the suspension of stationary teaching and regular scholarly communication in the information society does not cause such a dramatic breakdown as it would have had even a dozen or so years ago, in the "pre-Internet era". Although we have to be aware that the virtualization of scientific processes cannot take place overnight, ad hoc, forced by the crisis on the contrary, it takes time to implement sensibly and effectively, we already have many potentialities to act on and tools to choose. We can use them. It is important to acknowledge and appreciate this.

In a situation where standard teaching cannot be conducted, a method of non-stationary education, so-called distance learning (D-learning or dLearning) is used. This method of learning is characterized by a separation of the teacher from the student and of the student from the group of learners, replacing direct interpersonal communication (typical for conventional education) with communication mediated by communication technology (cf. e.g. Bednarek \& Lubina, 2008; Frania, 2017; Lewowicki \& Siemieniecki, 2009; Madej et al., 2016; McAvinia, 2016; Plebańska, 2011; Wierzbicka, 2019). The current crisis may contribute to a significant development of methods and techniques of distance learning, which in the future may have a positive effect in the form of an increase in the general level of education of societies, including adult education. A project of this kind has already been launched, for example, by the Warsaw Digital Centre (Pol. Centrum Cyfrowe).

With the implementation of distance learning, students have to work from home. The problem in continuing education in these circumstances may be common laziness or inability to focus and lack of discipline. Everyone knows what conditions are favorable for them to study and what conditions are not. For example, some people can only focus in a distraction-free environment of the library to which they currently have no access. 
The way the classes are conducted and the type of tasks assigned to the students have fundamentally changed now. However, this does not necessarily have to affect the amount of knowledge gained during performing these new tasks, because "who does not want to learn anyway will not do so" under any circumstances (Doda, 2020). The problem of engagement comes into play here, which may become smaller when the lecture hall is converted into a private room. Nevertheless, the fact that such a system of conducting classes requires more student's own work may have benefits as it fosters independence and good work organization. Pandemic is a technical test for the scholarly communication system, as mentioned above, but it is also a test of maturity for participants in the communication processes in science.

Further problems may arise in certain special cases. The first of these would be the conducting of the exams, difficult to organize online. Different platforms make it possible for students to take a test, but the reliability of the results is not very high. Thus, an oral examination in recorded Q\&A's session provided by an audio-video connection remains potentially the best solution. It is hard to imagine, however, this could be an option in the case of doctoral exams. Perhaps it would be worthwhile to design a more satisfactory mode of remote examination system for the future.

An even larger issue will be the suspension of field exercises, necessary e.g. for archaeologists. Students and researchers requiring access to specialized laboratories or laboratories with necessary equipment (e.g. students of the Academy of Fine Arts or faculties of medicine or natural sciences) are in a difficult situation, cut off from much-needed facilities. Not everything can be replaced by communication technologies. Representatives of humanities and social sciences, as theorists, are in a relatively better situation.

Although it seems that the current level of technological development is so high that we can rely on digital devices, in practice it sometimes turns out that technology may disappoint. Suffice to say that the most popular e-learning systems in Poland did not withstand the situation because they were not prepared to handle such intensive network traffic. These systems were subjected to a difficult test, which showed their unsuitability for critical situations. System designers should draw conclusions from this for the future.

We must also take into account those (hopefully infrequent) cases where students and academics face technological barriers. Such a barrier may be a lack of appropriate equipment, lack of access to a fast Internet connection, or lack of skills necessary to function efficiently only in an online environment (Świgoń, 2006).

As mentioned above, the enforced changes are too sudden for us to adapt easily to them. The human factor usually turns out to be the weak link. Students point out that it is better if the lecturers teach on a platform that they already know well. One of the group members said, "I lost 15 minutes of classes just because I was muted by the lecturer". Lecturers may also prepare short instruction manuals for students on how they should use the new tools. One hears the voices of young people who have problems with installing or operating unknown software (already mentioned technological barrier).

Lecturers and educators, must be aware that the current situation places new demands on them. They have to carry the burden of creating interesting and easy-to-learn materials for online classes. The existing models of classes must be changed. Lecturers have to develop a different skill-set than that sufficient to conduct onsite classroom lectures. This is an effort that needs to be made and another barrier that needs to be overcome - but all this, 
as e-learning practitioners point out, will quickly pay off. Perhaps in the future, thanks to the experience gained now, a higher percentage of academic teachers will reach for modern methods and tools, learned and used nolens volens during quarantine.

\section{Tools}

There are many tools available for implementing and maintaining the scholarly communication. Professionals and practitioners create and share special lists of tools for remote work, which can be very useful, especially now ${ }^{2}$. The Foundation for the Development of the Information Society (Pol. Fundacja Rozwoju Społeczeństwa Informacyjnego) has prepared a specific guide available online: Digital competence in times of pestilence - a scenario and other resources for learning and remote working.

Students mention following communicators and tools for remote work as the most frequently used: Skype, ClickMeeting, Google Hangouts Meet, Google Classroom, Webinar, COME, Discord, Teamspeak, Moodle, ClassDojo or Facetime. One of the students says, "I have recently had the pleasure of using all of these tools and I think they are great as scholarly communicators" (Żukowska, 2020). Students emphasize the usefulness of the Google Classroom, in which it is possible to assign exercises to specific students, enforce terms, and evaluate jobs - including adding comments (especially useful in evaluating text documents) (Doda, 2020). A Google account within institutional G Suite is set up for every student, so that everyone has access to all services of this provider. They are worth using.

According to one of the students,

(...) it would be most convenient and intuitive to combine Google and Discord services. The Google Hangouts Meet tool allows to organize classes online. Other Google services offer fast file exchange, creation of presentations, documents and group management (Google Classroom). An alternative to holding classes could be Discord, which has now abolished the user limit for video transmission on free servers. This service allows users to create their own servers to be used for communication purposes. A function of automatic audio muting when the user does not speak is included, which eliminates background noises in the transmission. The program allows users to modify the server for their specific needs. The browser version does not even require setting up an account. The free version of Discord allows to upload files up to $8 \mathrm{MB}$, which is completely sufficient to share students' work or shorter scholarly papers.

On the other hand, a tool like GoToWebinar is not very intuitive and one should think carefully before proposing it as the default tool of communication with students. It lacks the functionalities that can be required from such a software (shortcut to mute, clear menu, account management available from the application level).

The nature of regular classes, according to previous experience, is best reflected in a videoconference, especially since commonly used tools make it possible to share a desktop screen, e.g. a presentation, which usually supports the lecture. However, there are courses that are based on individual tasks, in which continuous interaction with the lecturer is not required. For such cases, platforms for sharing tasks, together with simple task editors, are good and sufficient tools (Doda, 2020).

\footnotetext{
${ }^{2}$ See e.g. Polish: https://bazawiedzy.socialtigers.pl/articles/90-narzedzi-do-pracy-zdalnej-megalista
} 
The multitude of tools, is pleasing on the one hand, but, on the other, it causes further problems. Students ask to standardize the selection of tools, which they and the lecturers have to share. For them, it is a major inconvenience to be forced to use many different platforms, chosen freely according to the lecturers' liking or knowledge. Reaching an agreement on this issue, which would allow all classes to take place on the same platform, would not only make it easier for students to learn and control the educational materials, but also foster coherence and order in instruction (Kozłowski, 2020). However, we are aware that this proposal is difficult to implement, in a way that would account both for the specifics of individual classes and for the lecturers' preferences and level of digital competence.

\section{What in return?}

One of the biggest problems we have faced in the first weeks of the lock-down was the closure of academic libraries. This limits the range of readings that students can prepare for classes, as not all texts have been digitized yet (older books and journals) or are available as electronic books (new scientific publications). This can be a big problem for people conducting their research or writing their thesis. Fortunately, some academic libraries are launching digitization services on a wider scale, enabling students and staff to order scans of the necessary texts. Administrators of scientific paid databases are expanding the range of publications available free of charge, providing open access to the resources previously available only by a paid subscription. Publishers make their books available as e-books for free, or at a discount of several dozen percent. Bookshops constantly encourage us to stay at home and read books, offering not only discounts, but also the possibility of free shipping of purchased books.

In this situation, the importance of home book collections is growing, although handy workshop facilities are usually available to scholars with a lot of experience and a higher degree - rarely to students. The role of open educational resources available to all (Kulczycki, 2016) and various types of online courses, which we already have at our disposal today, will grow in the future (to name just a few international examples: Merlot, MIT Open Courseware, Khan Academy, OpenLearn, Coursera; Polish examples: Copernicus College or Navoica). A search engine for open online courses can be found at https://www.mooc-list. $\mathrm{com} /$. Popular science channels on YouTube may play an important role. We are more aware of the role and importance of digital libraries and various types of repositories, social networks for scholars (academia.edu, researchgate.net), and finally, of various types of library catalogues available online and bibliographic databases providing valuable bibliographic information. Researchers should consider using these social networking sites, blogging platforms and microblogs more widely in scholarly communication (Tafiłowski, 2016).

The darker side of the phenomenon will probably be the inevitable increase of the degree of use of various types of pirate websites with scholarly papers (Bohannon, 2016) or websites services of which are in breach of copyright (or close to it). Internet Archive, for example, has been heavily criticized after it granted free, unlimited access to copyrighted works within the framework of the initiative called "National Emergency Library".

The changes taking place today will probably gradually facilitate access to scientific papers, and thus facilitate and improve scholarly communication processes. A crisis induces 
publishers to introduce certain facilities for researchers. It remains an open question whether these changes will be sustainable. We can only wish that the end of the quarantine will not bring the loss of access to scientific publications.

\section{The future}

All this will lead, as can be expected, to increased importance and development of access based on the Open Access philosophy. The current crisis may result in the development of Open Science, wider opening of access to research results, especially those financed by public funds, and the development of technology designed for these purposes. We may expect an accelerated virtualization of communication processes in science. Some changes are likely to occur in science metrics and bibliometrics systems, as the role of altmetric indicators may increase (Puckett Rodgers \& Barbrow, 2014).

Virtual space fosters creation of invisible colleges, i.e. informal groups of scholars coming from different institutions, usually distant from each other in geographical space. John Gresham wrote about the transformation of the invisible colleges, the concept of which was conceived as early as in the 17th century, into a digital college, or a cyberspace college (Gresham, 1994, 39). The pandemic may accelerate and intensify the processes of creating virtual colleges of this kind. This is an interesting problem, worth observing further.

According to Vincent Larivière, FeiShu and Cassidy R. Sugimoto,

The coronavirus (COVID-19) outbreak exposes an inconvenient truth about science: the current scholarly communication system does not serve the needs of science and society. More specifically, the crisis makes manifest two inefficiencies in the research system: the default to closed science and the overemphasis on elite, English-only publishing, irrespective of the context and consequences of the research (Larivière et al., 2020).

Such reservations have been raised for a long time, but now, in crisis, the problem becomes even more serious. It may also be possible to learn lessons for the future and to change the situation. The pandemic has clearly shown how important it is to make research results available in national languages. It has also shown how crucial it is for political decision-makers to realize that researchers everyday are facing problems more important than applying quantitative measures and position of universities in international rankings.

We do not know yet how the pandemic will affect the publishing process. For a long time now, interactions between authors, editors, and reviewers have been taking place via e-mail and Internet platforms designed for the purpose, so the pandemic should not have a major impact on the process. However, we know that the publishing process, at least for some journals, is being delayed. Editors work remotely, out of their offices, and reviewers are less willing to accept papers for evaluation. However, it is impossible to assess to what extent this is actually a result of an epidemiological threat ${ }^{3}$.

The pandemic and the resulting quarantine is a challenge and a demanding test, for researchers and lecturers, as well as for students. We are doomed to isolate and perform our duties using the Internet, with the applications and tools available. Regardless of when and how the pandemic will end, it has forced us to confront problems that we have

\footnotetext{
${ }^{3}$ More on long-term impact of COVID-19 on processes in discussion see for example Cochran, 2020.
} 
to solve on an ongoing basis. They will certainly cause changes in the process of scholarly communication that we will experience in the future, even if we are not able to predict them now. It is important that we prepare for the coming changes, and above all that we actively design our future.

\section{References}

Barjak, F. (2006). The Role of the Internet in Informal Scholarly Communication. Journal of the American Society for Information Science and Technology, 57(10), 1350-1367, https://doi.org/10.1002/ asi.20454

Bednarek, J., Lubina, E. (2008). Kształcenie na odległość. Podstawy dydaktyki. Warszawa: Wydaw. Naukowe PWN.

Bohannon, J. (2016). Who's Downloading Pirated Papers? Everyone. Science [online]. April 26, [05.08.2020], https://www.sciencemag.org/news/2016/04/whos-downloading-pirated-papers-everyone\#

Borgman, Ch.L. (2007). Scholarship in the Digital Age: Information, Infrastructure, and the Internet Cambridge, MA: MIT Press.

Cisek, S., Sapa, R. (2007). Komunikacja naukowa w Internecie - mity i rzeczywistość. In: W. Lubaszewski (ed.). Komputer - Człowiek - Prawo (39-49). Kraków: Wydaw. UJ.

Cochran, A. (2020). What Will We Learn About Scholarly Publishing as a Result of COVID-19? The Scholarly Kitchen [online]. April 28 [05.08.2020], https://scholarlykitchen.sspnet.org/2020/04/28/ what-will-we-learn-about-scholarly-publishing-as-a-result-of-covid-19/

Doda, S. (2020). Student - Wykładowca, przemyślenia na temat nauczania zdalnego [online]. Architekci recenzują, [05.08.2020], https://apirecenzje.blogspot.com/2020/04/student-wykadowca-przemyslenia-na-temat.html

Frania, M. (2017). Nowe media, technologie i trendy w edukacji. W kierunku mobilności i ksztatcenia hybrydowego. Kraków: Oficyna Wydawnicza „Impuls”.

Genoni, P., Merrick, H., Willson, M. (2014). Virtual Symposia: An Investigation into Scholarly Communities Online [online]. VALA2004 Proceedings [05.08.2020], https://www.vala.org.au/ vala2004/2004pdfs/28GeMeWi.PDF

Genoni, P., Merrick, H., Willson, M. (2005). Community, Communication, Collaboration: Scholarly Practice in Transformation. Proceedings of the Next Wave of Collaboration: Educause Australasia 2005, April 5-8, 2005 [online]. Auckland, NZ: Curtin University, [05.08.2020], http://espace.library. curtin.edu.au/R?func=dbin-jump-full\&local_base=gen01-era02\&object_id=19204

Kotuła, S.D. (2013). Komunikacja bibliologiczna wobec World Wide Web. Lublin: Wydaw. UMCS.

Kozłowski, M. (2020). Komunikacja naukowa w czasach pandemii [online]. Architekci recenzują, [05.08.2020], https://apirecenzje.blogspot.com/2020/04/komunikacja-naukowa-w-czasach-pandemii.html

Krakowska, M. (2008). Nowe formy komunikacji społecznej w europejskiej przestrzeni edukacyjnej. Kraków: Wydaw. UJ.

Kulczycki, E. (2012). Komunikacja naukowa, czyli co? [online]. Warsztat badacza, [05.08.2020], http:// ekulczycki.pl/teoria_komunikacji/komunikacja-naukowa-czyli-co/

Kulczycki, E. (2016). Otwarte Zasoby Edukacyjne w edukacji akademickiej [online]. Warsztat badacza, [05.08.2020], http://ekulczycki.pl/warsztat_badacza/otwarte-zasoby-edukacyjne-w-edukacjiakademickiej/

Larivière V., Shu F., Sugimoto C. R. (2020). The Coronavirus (COVID-19) Outbreak Highlights Serious Deficiencies in Scholarly Communication [online]. London: The London School of Economics and Political Science, [05.08.2020], https://blogs.lse.ac.uk/impactofsocialsciences/2020/03/05/ the-coronavirus-covid-19-outbreak-highlights-serious-deficiencies-in-scholarly-communication/ 
Lewowicki, T., Siemieniecki, B. (2009). Ksztatcenie na odległość w praktyce edukacyjnej. Toruń: Wydaw. Adam Marszałek.

Madej, M., Faron, A., Maciejewski, W. (2016). E-learning w dydaktyce szkoty wyższej. Założenia, doświadczenia, rekomendacje. Wrocław: Wyższa Szkoła Handlowa.

McAvinia, C. (2016). Online Learning and its Users. Lessons for Higher Education. Oxford: Chandos Publishing.

Nahotko, M. (2008) Czy nastąpi koniec druku? Komunikacja naukowa XXI wieku oparta na publikacjach elektronicznych. In: D. Pietruch-Reizes, W. Babik (eds.) Wymiana informacji i rozwój profesjonalnych ustug informacyjnych w edukacji, nauce i kulturze na rzecz spoteczeństwa opartego na wiedzy (78-91). Katowice: PTIN.

Nahotko, M. (2010). Komunikacja naukowa w środowisku cyfrowym: globalna biblioteka cyfrowa w informatycznej infrastrukturze nauki. Warszawa: Wydaw. SBP.

Plebańska, M. (2011). E-learning: tajniki edukacji na odlegtość. Warszawa: Wydaw. C. H. Beck.

Puckett Rodgers, E., Barbrow, S. (2014). Wskaźniki altmetryczne i ich rosnące znaczenie w bibliotekach naukowych, Biuletyn EBIB [online], 6(151), [05.08.2020], http://ebibojs.pl/index.php/ebib/ article/view/355

Regazzi, J. (2015). Scholarly Communications: A History From Content as King to Content as Kingmaker. Lanham, MD: Rowman \& Littlefield.

Sapa, R. (2009). Metodologia badań obszaru pośredniczenia w komunikacji naukowej z perspektywy nauki o informacji. Kraków: Wydaw. UJ.

Świgoń, M. (2006). Bariery informacyjne. Warszawa: Wydaw. SBP.

Świgoń, M. (2015). Dzielenie się wiedza i informacją: specyfika nieformalnej komunikacji w polskim środowisku akademickim. Olsztyn: Wydaw. UWM.

Tafiłowski, P. (1016). Media społecznościowe jako źródło informacji bibliograficznej w naukach humanistycznych. Komunikat z badań. Zagadnienia Informacji Naukowej, 54(1), 55-66, https:// doi.org/10.36702/zin.287

Wierzbicka, A. (2019). Dydaktyczne i komunikacyjne aspekty e-edukacji akademickiej. Łódź: Wydaw. Uniwersytetu Łódzkiego.

Żukowska, M. (2020). Komunikacja naukowa - raport [online]. Architekci recenzują, [05.08.2020], https://apirecenzje.blogspot.com/2020/04/komunikacja-naukowa-raport.html

\title{
Wpływ zagrożenia epidemiologicznego na procesy komunikacji naukowej. Uwagi wstępne
}

\begin{abstract}
Abstrakt
Cel/teza: Celem artykułu jest zaprezentowanie refleksji oraz propozycja dyskusji nad zmianami w komunikacji naukowej w okresie kryzysu epidemiologicznego, zarówno w zakresie badań naukowych, jak i dydaktyki uniwersyteckiej.

Koncepcja/metody badań: Prezentowane rozważania dotyczące zmian w komunikacji naukowej mają charakter refleksji teoretycznej. Tekst powstał z dyskusji internetowych ze studentami II roku studiów stacjonarnych na kierunku Architektura przestrzeni informacyjnych, w ramach przedmiotu Komunikacja naukowa w marcu $2020 \mathrm{r}$.

Wyniki i wnioski: Zagrożenie epidemiologiczne związane z rozprzestrzenianiem się wirusa COVID-19, dezorganizujące w ostatnich tygodniach nasze życie społeczne, nie pozostanie bez wpływu również na procesy komunikowania w nauce. Wydaje się, że najbardziej oczywistymi skutkami
\end{abstract}


pandemii w interesującym nas zakresie będą rozwój metod i technologii nauczania zdalnego oraz wzrost zasobów tekstów naukowych w wolnym dostępie. Zmiany są nieuchronne, w związku z czym proponujemy refleksję nad ich kierunkiem, byśmy mogli przygotować się na nie oraz czynnie uczestniczyć w ich projektowaniu.

Oryginalność/wartość poznawcza: Podjęcie tego typu rozważań wydaje się być uzasadnione bieżącymi wypadkami. Znajdujemy się obecnie w centrum procesu zmian, nad którymi należy debatować po to, by w miarę możliwości nadawać im pożądany kierunek.

\section{Słowa kluczowe}

COVID-19. Komunikacja naukowa. Zdalne nauczanie.

PIOTR TAFIŁOWSKI is Associate Professor in Department of Information Studies, Faculty of Journalism, Information and Book Studies, University of Warsaw. In his research and teaching he focuses on history and current state of social and scholarly communication and on issues of information science. Among his recent publications are two monographs: Inkunabuły zawierające treści geograficzne w zbiorach polskich. Z dziejów komunikacji społecznej i naukowej w dawnej Polsce (Warszawa 2017) and Pomiędzy cywilizacjami. Wojna i praktyki komunikacyjne na pograniczu chrześcijańsko-muzułmańskim na przełomie średniowiecza i ery nowożytnej (Oświęcim 2019).

Contact to the Author:

p.tafilowski@uw.edu.pl

Department of Information Studies

Faculty of Journalism, Information and Book Studies

University of Warsaw

Nowy Świat 69

00-046 Warsaw, Poland 